\title{
STRATEGI PENGEMBANGAN KOPERASI TANI SAWIT BAROKAH KECAMATAN TEBO ULU KABUPATEN TEBO (Studi Kasus Koperasi Di Desa Teluk Kasai Rambahan)
}

\section{THE DEVOLOPMENT STRATEGY OF BAROKAH OIL PALM FARMER COOPERATIVES, TEBO ULU SUBDISTRICT TEBO DISTRICT} (Case Study Of Cooperative In Teluk Kasai Rambahan)

\author{
${ }^{1}$ Evo Afrianto, ${ }^{2}$ Ari Aryanti, ${ }^{3}$ Pitriani \\ ${ }^{123}$ Program Studi Agribisnis, Fakultas Pertanian, Universitas Muara Bungo, Jl. Pendidikan, \\ RT. 10 RW. 02 No. 10 Kelurahan Sungai Binjai. Kecamatan Bathin III. Kabupaten Bungo, \\ Jambi 37228, Indonesia \\ evo_juventini@yahoo.com, ariaryanti78@gmail.com, pitrianianto@yahoo.com
}

\begin{abstract}
ABSTRAK
Koperasi Tani Sawit Barokah merupakan salah satu koperasi yang memiliki anggota terbanyak. Penelitian ini dilaksanakan pada tanggal 24 Desember 2019 sampai 24 Januari 2020 dengan tujuan untuk mengetahui faktor internal dan eksternal yang mempengaruhi pengembangan koperasi tani sawit barokah di Desa Teluk Kasai Rambahan dan untuk mengetahui strategi pengembangan Koperasi Tani Sawit Barokah di Desa Teluk Kasai Rambahan.

Metode penelitian yang digunakan adalah metode survei yaitu Koperasi Tani Sawit Barokah di Desa Teluk Kasai Rambahan Kecamatan Tebo Ulu Kabupaten Tebo. Penelitian ini menggunakan Analisis SWOT.

Hasil penelitian menunjukkan bahwa Faktor Internal yang dimiliki Koperasi Tani Sawit Barokah di Desa Teluk Kasai Rambahan adalah kekuatan berupa sumber modal sendiri, anggota sangat mudah ditemukan dan modal simpanan pokok awal terjangkau dan kelemahannya berupa tidak ada investasi dari pihak lain, menghasilkan sawit tidak menentu dan pembukuan dilakukan setiap tahun. Faktor Eksternal adalah peluang berupa kualitas kelapa sawit yang sangat baik, tidak ada pesaing dalam penjualan sawit koperasi, dan keikutsertaan dalam pameran agar menjual sawit ke koperasi, dan ancamannya berupa pesaing dari koperasi yang sejenis, kurangnya kegiatan penjualan, kurangnya mesin/alat yang digunakan dan image koperasi tani sawit barokah yang masih asing di PT. RAU. Strategi pengembangan Koperasi Tani Sawit Barokah di Desa Teluk Kasai Rambahan adalah peningkatan modal dengan cara penambahan investasi atau pinjaman dari pihak lain, memperluas daerah penjualan, pelatihan manajemen kepada ketua, memanfaatkan modal simpanan pokok yang ada untuk penambahan kelapa sawit untuk menguasai pasar ketika belum ada pesaing dari koperasi lainnya, menciptakan penjualan yang baru koperasi, memperluas pangsa pasar, mempertahankan kualitas sawit, meningkatkan penjualan sawit, mengadakan kerjasama dengan PT lain dalam hingga luar wilayah, pengoptimalkan penggunaan mesin/alat teknologi untuk memperlancar proses penjualan.
\end{abstract}

Kata Kunci : Strsategi Pengembangan. Koperasi Tani Sawit Barokah

ABSTRACT

Koperasi Tani Sawit Barokah is one of the cooperatives that has the most members. This research was conducted on December 24, 2019 to January 24, 2020 with the aim of knowing the internal and external factors that affect the development of the Barokah oil palm 
cooperative in Teluk Kasai Rambah Village and to find out the strategy for developing the Barokah Farmer Cooperative in Teluk Kasai Rambahan Village.

Theresearch method used was a survey method, namely the Barokah Palm Farmers Cooperative in Teluk Kasai Rambahan Village, Tebo Ulu District, Tebo Regency. This study uses a SWOT analysis.

The results showed that the internal factors owned by the Koperasi Tani Sawit Barokah in Teluk Kasai Rambahan Village were the strengths in the form of their own source of capital, the members were very easy to find and the initial principal savings were affordable and the weaknesses were no investment from other parties, the production of palm oil was uncertain and bookkeeping done every year. External factors are opportunities in the form of very good quality palm oil, there are no competitors in the sale of cooperative palm oil, and participation in exhibitions to sell palm oil to cooperatives, and threats in the form of competitors from similar cooperatives, lack of sales activities, lack of machines / tools used and image of barokah oil palm farmer cooperatives that are still foreign to PT. RAU. The strategy for developing the Barokah Farmers Cooperative in Teluk Kasai Rambah Village is to increase capital by increasing investment or loans from other parties, expanding sales areas, training management to the chairman, utilizing existing principal savings capital to add oil palm to dominate the market when there are no competitors. from other cooperatives, creating new sales cooperatives, expanding market share, maintaining the quality of palm oil, increasing palm oil sales, entering into cooperation with other PTs within and outside the region, optimizing the use of machines / technology tools to streamline the sales process.

Keywords: Development Strategy. Barokah Palm Farmers Cooperative

\section{PENDAHULUAN}

Asas Koperasi Indonesia adalah kekeluargaan dan kegotong- royongan. Selain itu juga, menurut UU No. 25 tahun 1992 Pasal 5 disebutkan bahwa Azas atau Prinsip koperasi, yaitu, Keanggotaan bersifat sukarela dan terbuka, 11 Pengelolaan dilakukan secara demokratis, Pembagian Sisa Hasil Usaha (SHU) dilakukan secara adil sebanding dengan besarnya jasa usaha masing-masing anggota (adil anggota tersebut dalam koperasi) pemberian balas jasa yang terbatas terhadap modal Kemandirian Pendidikan perkoprasian (UU No.25 Tahun 1992, Pasal 5).

Berbagai program pengembangan sektor pertanian dan industri rakyat yang pada umumnya dikelola pengusaha kecil bisa dijalankan dengan skala ekonomi yang lebih besar, lebih efisien dan efektif dengan adanya koperasi (Syahrudin,2003). Suatu hal yang sangatlah tepat jika ingin memperbaiki tatanan ekonomi yang ada di negara-negara yang memiliki daerah pertanian yang luas adalah dengan membangun daerah tersebut yang nantinya pasti akan ikut berperan serta dalam memperbaiki struktur tatanan ekonomi di negara yang besangkutan (Fikriman, 2017). Sawit merupaka suatu komoditas unggulan di Provinsi Jmabi dan produktivitas bisa dipengaruh dari dalam perkebunan sawit itu sendiri seperti faktor kerja serta faktor luar perkebunan sawit itu sendiri (Fikriman dan Herdiansyah, 2017). Koperasi juga merupakan tempat yang efektif bagi anggotanya untuk saling bekerjasama dan menghimpun kekuatan guna mengatasi berbagai hambatan struktural, membuka akses kepada pasar, modal, informasi dan teknologi, dengan mengoptimalkan potensi dan memanfaatkan peluang usaha yang terbuka.

Provinsi Jambi termasuk salah satu provinsi di Indonesia yang memiliki perkembangan terhadap peningkatan jumlah koperasi. Provinsi Jambi pada tahun 2017 memiliki koperasi sebanyak 1.952 unit, sedangkan pada 2018 jumlah koperasi di Provinsi Jambi adalah 2.764 unit sehingga dapat disimpulkan bahwa 
dalam waktu satu tahun terjadi penambahan koperasi sebanyak 812 unit.

Berdasarkan Provinsi Jambi terdapat 11 Kabupaten/Kota. Provinsi Jambi pada tahun 2019 terdapat 3.747 koperasi, dari 3.747 koperasi tersebut sebanyak 1.880 koperasi aktif dan yang tidak aktif 1.867 koperasi.Kota Jambi urutan tertinggi dengan jumlah 381 koperasi, sedangkan Kota Sungai Penuh urutan yang paling terendah dengan jumlah 94 koperasi. Kabupaten Tebo termasuk kedalam urutan koperasi yang rendah yaitu urutan sepuluh dengan jumlah 106 koperasi, sedangkan koperasi yang tidak aktif di Kabupaten Tebo urutan tertinggi kedua dengan jumlah 250 koperasi. Kabupaten Tebo memiliki 12 Kecamatan, 5 Kelurahan, dan 107 Desa. Berikut daftar Kecamatan dan jumlah Desa/Kelurahan di Kabupaten Tebo.

Kecamatan Tebo Ulu memiliki Desa/ Kelurahan yang tinggi dengan jumlah 17 Desa/Kelurahan, selanjutnya Tebo Tengah dan sumay memiliki jumlah yang sama yaitu 12 Desa/Kelurahan, selanjutnya Tebo Ilir dengan jumlah 11 Desa/Kelurahan, VII Koto dengan jumlah 10 Desa/ Kelurahan, Rimbo Ilir dengan jumlah 9 Desa/Kelurahan, Muara Tabir dan Rimbo Bujang dan Serai Serumpun memiliki jumlah yang sama yaitu 8 Desa/Kelurahan, VII Koto Ilir dan Rimbo Ulu dengan jumlah 6 Desa/Kelurahan, dan yang terakhir Tengah Ilir dengan jumlah yang paling sedikit yaitu 6 Desa/Kelurahan.

Kecamatan Tebo ulu terdapat 10 Koperasi yang termasuk dalam Dinas Koperasi dan UKM, dari 10 koperasi tersebut sebanyak 2 koperasi yang masih aktif dan 8 koperasi yang sudah dibubarkan. Koperasi sebagai wadah pusat pelayanan kegiatan perekonomian yang harus didirikan serta dikembangkan dengan perhitungan dan perkembangan ekonomi yang membutuhkan pemikiran yang jauh ke depan. Sedangkan telah kita sadari, bahwa tingkat pendidikan masyarakat dipedesaan kususnya masyarakat masih sangat rendah dan rakyat dipedesaan masih sangat kuat terikat oleh kehidupan dan alam pikir yang tradisional. Sehingga prioritas utama yang harus dipikirkan dan diusahakan adalah menyadarkan masyarakat tentang arti penting mengenai koperasi.

$$
\text { jumlah koperasi yang ada di }
$$

Kecamatan Tebo Ulu sebanyak 10 koperasi, yang aktif dan masih berjalan ada 2 koperasi dan 8 koperasi yang sudah dibubarkan. Dapat lihat juga koperasi tani sawit barokah menjadi salah satu koperasi dengan jumlah anggota nya yang terbanyak yaitu 195 Orang, anggota lakilaki sebanyak 180 orang sedangkan anggota perempuan sebanyak 15 orang.

Koperasi tani sawit barokah di Desa Teluk Kasai rambahan merupakan koperasi yang berdiri pada Tahun 2000 yang sudah memiliki badan hukum, dengan anggota sebanyak 195 orang, di dalam Koperasi tani sawit barokah juga terdapat sembilan Gabungan Kelompok Tani (GAPOKTAN), umumnya pada setiap Koperasi ingin mencapai tujuan yang telah ditetapkan, tujuan tersebut untuk mensejahterakan dan memperbaiki perekonomian masyarakat, namun koperasi tani sawit barokah pada setiap tahun nya pada survei awal mengalami penurunan pada modal.

Berdasarkan permasalahan di atas, peneliti tertarik untuk melakukan suatu penelitian.

Adapun tujuan penelitian ini adalah Untuk mengetahui faktor internal dan eksternal yang mempengaruhi pengembangan koperasi tani sawit barokah di Desa Teluk Kasai Rambahan. Dan Untuk mengetahui strategi pengembangan koperasi tani sawit barokah di Desa Teluk Kasai Rambahan Kecamatan Tebo Ulu Kabupaten Tebo.

\section{METODOLOGI PENELITIAN}

Menurut Sugiyono (2009) metode survei digunakan untuk mendapatkan data dari tempat tertentu yang alamiah (bukan 
buatan) tetapi peneliti melakukan perlakuan dalam pengumpulan data, misalnya mengedarkan kuisioner, test, wawancara terstruktur dan sabagainya. Dimana dalam penelitian ini menjadi objek penelitian adalah koperasi tani sawit barokah di Desa Teluk Kasai Rambahan, dimana Desa Teluk Kasai Rambahan merupakan desa yang koperasi nya aktif dan memiliki jumlah anggota yang terbanyak dari koperasi yang ada di Kecamatan Tebo Ulu.

Analisis SWOT adalah identifikasi berbagai faktor secara sistematis untuk merumuskan strategi koperasi tani sawit barokah di Desa Teluk Kasai Rambahan.. Analisis ini didasarkan pada logika yang dapat memaksimalkan kekuatan (Strengths) dan peluang (Opportunities), namun secara bersamaan dapat meminimalkan kelemahan (Weaknesses) dan ancaman (Threats). Perencanaan strategi koperasi tani sawit barokah didesa teluk kasai rambahan (kekuatan, kelemahan, peluang dan ancaman) dalam kondisi yang ada saat ini. Berikut adalah langkah-langkah selanjutnya setelah diperoleh analisis mengenai kekuatan, kelemahan, peluang dan ancaman pada koperasi tani sawit barokah didesa teluk kasai rambahan.

\section{Analisis Faktor Internal dan Eksternal}

Berikut adalah tahapan-tahapan analisis IFAS (internal Factor Analysis Summary) dan EFAS (Eksternal factor Analysis Summary) untuk mengindentifikasi faktor internal dan eksternal didalam perusahaan (Rangkuti, 2005) yaitu :

1. Melakukan identifikasi dan menuliskannya pada kolom 1, tentang kekuatan dan kelemahan dari perusahaan.

2. Menetapkan ranting dari masingmasing faktor kekuatan dengan angka 4 (sangat pnting), 3 (penting), 2 (cukup penting), 1 (tidak penting). Sedangkan kelemahan 1 (sangat penting), 2 (penting), 3 (cukup penting), 4 ( tidak penting).

3. Menetapkan bobot faktor internal pada kolom 2, mulai dari 1,0 (paling penting) sampai 0,0 (tidak penting), total semua bobot harus berjumlah 1,0.

4. Pada aspek kekuatan dan kelemahan menggunakan skala 0-1. Setiap aspek mendapatkan skor tertinggi terbanyak 0,5. Sehingga formulasi terbaiknya adalah 0,5 di bagi angka 10 . Berikut adalah formulasi perhitungan pembobotan dan rating terbaik :

a. Faktor kekuatan dan faktor peluang

Setiap rating dilakukan dengan hasil pembagian dari skor maksimum pada setiap aspek yaitu 0,5 . Berikut ini hasil perumusan bobot faktor kekuatan :

- $\quad$ Rating $1=1 \times(0,5: 10)=0,05$

- $\quad$ Rating $2=2 \times(0,5: 10)=0,10$

- $\quad$ Rating $3=3 \times(0,5: 10)=0,15$

- Rating $4=4 \times(0,5: 10)=0,20$

b. Faktor kelemahan dan ancaman

- $\quad$ Rating $4=1 \times(0,5: 10)=0,05$

- $\quad$ Rating $3=2 \times(0,5: 10)=0,10$

- $\quad$ Rating $2=3 \times(0,5: 10)=0,15$

- Rating $1=4 \times(0,5: 10)=0,20$

5. Mengalikan rating dengan bobot dengan peringkatnya untuk memperoleh skor terbobot yang akan ditulis pada kolom 4.

6. Menjumlahkan seluruh skor terbobot sehingga memperoleh total dari skor terbobot. Total skor terbobot mempunyai interval dari angka 4,0 (baik sekali) hingga 1,0 (buruk).

\section{Matriks IE (Internal dan Eksternal)}

Matriks Internal dan Eksternal digunakan untuk menggambarkan kondisi strategi pada suatu perusahaan. Matriks ini diperoleh dari hasil skor pada faktor internal dan eksternal. 
Total Faktor Strategi Internal

\begin{tabular}{|c|c|c|c|c|}
\hline \multirow{4}{*}{$\begin{array}{c}\text { Total Faktor } \\
\text { Strategi Eksternal }\end{array}$} & \multirow[b]{2}{*}{ Tinggi 3,00} & $\begin{array}{l}\text { Kuat } \\
\qquad 4,00\end{array}$ & $\begin{array}{l}\text { Rata-rata } \\
3,00\end{array}$ & $\begin{array}{l}\text { Lemah } \\
\qquad 2,00\end{array}$ \\
\hline & & $\begin{array}{c}\text { I } \\
\text { Pertumbuhan }\end{array}$ & \begin{tabular}{|c} 
II \\
Pertumbuhan
\end{tabular} & $\begin{array}{c}\text { III } \\
\text { Penciutan }\end{array}$ \\
\hline & Menengah & $\begin{array}{c}\text { IV } \\
\text { Stabilitas }\end{array}$ & $\begin{array}{c}\text { V } \\
\text { Pertumbuhan } \\
\text { Stabilitas }\end{array}$ & $\begin{array}{l}\text { VI } \\
\text { Penciutan }\end{array}$ \\
\hline & $\begin{array}{c}2,00 \\
\text { Rendah } \\
1,00\end{array}$ & $\begin{array}{c}\text { VII } \\
\text { Pertumbuhan }\end{array}$ & $\begin{array}{c}\text { VIII } \\
\text { Pertumbuhan }\end{array}$ & $\begin{array}{c}\text { IX } \\
\text { Likuidasi }\end{array}$ \\
\hline
\end{tabular}

Gambar 1. Matriks Internal dan Eksternal

\section{Matriks SWOT}

Matriks SWOT digunakan dalam identifikasi sebagai faktor secara sistematis untuk merumuskan strategi perusahaan. Analisis Matriks SWOT ini

\section{menggunakan logika dalam} memaksimalkan pemakaian kekuatan dan peluang untuk memanipulasi kelemahan dan meminimalkan ancaman.

\begin{tabular}{|c|l|l|} 
IFAS & $\begin{array}{l}\text { STRENGHTS (S) } \\
-\begin{array}{l}\text { Tentukan faktor- } \\
\text { faktor kekuatan } \\
\text { internal }\end{array}\end{array}$ & $\begin{array}{c}\text { WEAKNESSES (W) } \\
-\quad \begin{array}{l}\text { Tentukan faktor- } \\
\text { faktor kelemahan } \\
\text { internal }\end{array}\end{array}$ \\
$\begin{array}{c}\text { EPORTUNITIES (O) } \\
\text { Menentukan } \\
\text { faktor- faktor } \\
\text { peluang eksternal }\end{array}$ & $\begin{array}{l}\text { Strategi SO : } \\
\text { Ciptakan strategi yang } \\
\text { menggunakan kekuatan } \\
\text { untuk memanfaatkan } \\
\text { peluang }\end{array}$ & $\begin{array}{l}\text { Strategi WO: } \\
\text { Ciptakan strategi yang } \\
\text { meminimalkan } \\
\text { kelemahan untuk } \\
\text { memanfaatkan peluang }\end{array}$ \\
\hline $\begin{array}{l}\text { THREATHS (T) } \\
\text { Menentukan } \\
\text { faktor- faktor } \\
\text { ancaman } \\
\text { eksternal }\end{array}$ & $\begin{array}{l}\text { Strategi ST: } \\
\text { Ciptakan strategi yang } \\
\text { menggunakan kekuatan } \\
\text { untuk mengatasi } \\
\text { ancaman }\end{array}$ & $\begin{array}{l}\text { Strategi WT: } \\
\text { Ciptakan strategi yang } \\
\text { meminimalkan } \\
\text { kelemahan dan } \\
\text { menghindari ancaman }\end{array}$ \\
\hline
\end{tabular}

Sumber : Freddy Rangkuti, 2009

Keterangan : Strategi SO (StrenghtsOpportunities), dalam situasi ini perusahaan perlu melakukan pengembangan bisnis yang agresif, yaitu memanfaatkan kekuatan yang substansial untuk menciptakan bisnis baru atau mengembangkan bisnis yang ada. Strategi dalam kuadran SO disebut sebagai strategi 
agresif.Strategi ST (Strengts-Threats), dalam situasi ini perusahaan perlu melakukan diversifikasi produk atau bisnis, melalui mengembangkan produkproduk unggul. Strategi dalam kuadran ST disebut sebagai strategi diversifikasi.Srategi WO (WeaknessesOpportunities), dalam situasi ini manajemen harus melakukan analisis terhadap kelemahan sehingga mampu menghilangkan kelemahan utama itu. Strategi dalam kuadran WO disebut sebagai strategi balik arah.Strategi WT (Weaknesses-Threats), dalam situasi ini manajemen harus melakukan analisis terhadap kelemahan utama yang ada sekaligus menghindari ancaman. Strategi pada kuadran WT disebut sebagai strategi bertahan.

\section{HASIL DAN PEMBAHASAN}

Faktor Internal dan Eksternal Pada Koperasi Tani Sawit Barokah di Desa Teluk Kasai Rambahan Kecamatan Tebo Ulu Kabupaten Tebo.

Faktor Internal :Sumber Daya Manusia (Anggota)

Sumber Daya Manusia (SDM) pada Koperasi Tani Sawit Barokah yaitu jumlah anggota yang ada pada Koperasi Tani Sawit Barokah sebanyak 195 orang. Tingkat ketersediaan jumlah anggota yang ada di daerah Desa Teluk Kasai Rambahan Kecamatan Tebo Ulu Kabupaten Tebo banyak karena masyarakat banyak tertarik untuk bekerjasama dengan koperasi tani sawit barokah ini dikarenakan harga penjualan koperasi yang tinggi. Oleh karena itu Bapak Abdul Roni S.Pd sangat mudah mencari sendiri anggota dari masyarakat desa. Anggota yang ada pada koperasi Tani Sawit Barokah di Desa Teluk Kasai Rambahan ini berasal dari masyarakat Desa yaitu berasal dari Desa Teluk Kasai Rambahan.

Pendidikan terakhir anggota yang ada pada koperasi Tani Sawit Barokah di Desa Teluk Kasai Rambahan adalah sebagian ada yang kelulusan Sekolah Dasar (SD), tetapi banyak anggota koperasi yang kelulusan Sekolah Menengah Atas (SMA). Menghasilkan sawit koperasi tidak menentu karena penjualan yang tidak menentu atau sesuai dengan kematangan sawit. Kerja anggota dalam satu minggu tidak menentu. Anggota yang berada pada koperasi Tani Sawit Barokah di Desa Teluk Kasai Rambahan ini tidak terikat jam kerja karena tidak setiap harinya kerja untuk panen sawit koperasi. Untuk pelatihan yang diberikan kepada anggota untuk meningkatkan kualiatas kerja diberikan langsung oleh pemerintah Kabupaten Tebo yang berupa pelatihan akuntasi koperasi berbasis komputer dan pelatihan penilaian kesehatan koperasi, pelatihan ini bertjuan untuk memperbaiki kualitas koperasi, pengurus harus bisa membuat laporan akuntansi berbasis komputer setelah mengikuti pelatihan. Pembinaan yang dilakukan pemerintah jarang dilakukan jika untuk pembinaan tentang koperasi tani sawit barokah, tetapi pemerintah memberikan pembinaan tentang manajemen yang baik untuk ketua koperasi dan pembinaan GAPOKTAN koperasi tani sawit barokah sebagai kelompok yang teladan yang menjadi panduan bagi para petani sawit sekitarnya dan dapat mengembangkan perkebunan khususnya kelapa sawit dimasa depan sebagai bentuk kepedulian terhadap kemajuan koperasi dan daerah (Lampiran 2).

Menurut Hasibuan (2006), Sumber daya manusia merupakan penyiapan dan pelaksanaan suatu rencana yang terkoordinasi untuk menjamin bahwa sumber daya manusia yang ada dapat dimanfaatkan dengan sebaik-baiknya untuk mencapai tujuan organisasi. manajemen sumber daya manusia merupakan suatu strategi dan menerapkan fungsi-fungsi manajemen yaitu planning, organizing, leading dan controlling, dalam setiap aktivitas/fungsi operasional sumber daya manusia. Sumber Daya Manusia mulai dari proses penarikan, seleksi, pelatihan dan pengembangan, penempatan 
yang meliputi promosi, demosi dan transfer, penilaian kinerja, pemberian kompensasi, hubungan industrial, hingga pemutusan hubungan kerja, yang ditujukan bagi peningkatan kontribusi produktif dari sumber daya manusia organisasi terhadap pencapaian tujuan organisasi secara lebih efektif dan efisien.

Permodalan :Jumlah simpanan pokok pada koperasi Tani Sawit Barokah di Desa Teluk Kasai Rambahan ini \pm Rp. 800.000,yaitu jumlah uang yang wajib dibayarkan oleh anggota kepada koperasi pada saat masuk menjadi anggota, sumber simpanan pokok yaitu diperoleh yaitu sumber modal sendiri dari anggota. Tidak ada bantuan modal dari pemerintah untuk koperasi ini. Koperasi Tani Sawit Barokah di Desa Teluk Kasai Rambahan ini tidak ada investasi dari pihak lebih dari manapun. Biaya yang dikeluarkan untuk anggota perbulan kurang dari Rp. 700.000,- yaitu Rp. 500.000,- dikarenakan tergantung seberapa banyak penjualan yang dihasilkan dan ketika tidak menjual sawit koperasi, anggota bekerja pada sawit koperasi yang dipimpin oleh Bapak Abdul Roni S.Pd sendiri.

$$
\text { Biaya yang dikeluarkan }
$$

perbulannya sebanyak \pm Rp. 2.000.000,setiap bulannya dan biaya yang dikeluarkan untuk biaya operasional adalah sebanyak Rp. 2.000.000,- setiap bulannya. Sistem administrasi keuangan pada koperasi Tani Sawit Barokah di Desa Teluk Kasai Rambahan adalah memisahkan semua uang milik pribadi dengan uang koperasi. Pembukuan keuangan menyangkut modal biaya penjualan dilakukan setiap tahunnya. Perputaran modal pada koperasi ini kurang lancar dikarenakan penjualan yang tidak menentu dan laporan keuangan yang kurang efektif sehingga menyebabkan perputaran modal kurang lancar (Lampiran $2)$.

Menurut Weston dan Brigham
(2001), bahwa modal kerja adalah
investasi perusahaan pada aktiva jangka

pendek, seperti kas, sekuritas yang mudah dipasarkan, piutang usaha dan persediaan. Modal kerja adalah nilai aktiva atau harta yang dapat segera dijadikan uang kas dan digunakan perusahaan untuk keperluan sehari-hari, misalnya untuk membayar gaji pegawai, pembelian bahan mentah, membayar ongkos angkutan, membayar hutang dan sebagainya. Pengelolaan modal kerja akan sangat menentukan posisi keuangan perusahaan, sehingga dalam setiap penggunaan modal kerja dapat tercapai tujuan suatu perusahaan jika adanya suatu keseimbangan dalam hal penyediaan dan penggunaan modal kerja tersebut. Modal kerja yang efektif yang berarti jumlah modal kerja yang dapat memenuhi kebutuhan akan aktivitas yang dilakukan oleh perusahaan.

\section{Faktor Eksternal}

Pemasaran :Penjualan sawit koperasi ini sangat mudah dipasarkan dikarenakan sawit ini penjualannya melalui koperasi. Kualitas sawit koperasi ini sangat baik karena koperasi ini selain kesuburan pohon dan koperasi juga memperhatikan proses pemanenan agar tidak salah memetik sebelum waktunya panen jika salah maka dapat mengurangi kualitas sawit. Harga sawit koperasi tinggi karena penjualan melalui koperasi. Penjualan sawit koperasi Tani Sawit Barokah ini yaitu lokal, luar Kabupaten hingga luar Provinsi. Hasil penjualan perbulan dari koperasi Tani Sawit Barokah di Desa Teluk Kasai Rambahan adalah \pm dari Rp. 400.000.000,-

Kegiatan penjualan sawit kurang banyak dilakukan karena penjualan tergantung pada kematangan atau siap panennya kelapa sawit. Upaya yang dilakukan untuk penarik agar menjualkan sawit koperasi yaitu dengan ikut serta dalam pameran karena sangat berpengaruh dalam meningkatkan penjualan dan untuk memperkenalkan lebih luas tentang pengaruh harga penjualan sawit yang melalui koperasi. Sedikit ada kendala dalam penjualan sawit koperasi yaitu 
image koperasi yang masih asing di PT. RAU .Tingkat persaingan dalam koperasi yang sejenis sangat banyak karena selain dari Kecamatan Tebo Ulu terdapat juga di Kecamatan sebelah beberapa koperasi yang sama berhubungan dengan kelapa sawit . Sedangkan tingkat persaingan dalam penjualan sawit pada koperasi Tani Sawit Barokah di Desa Teluk Kasai Rambahan ini tidak ada karena koperasi ini adalah salah satu koperasi yang ada di Kecamatan Tebo Ulu yang memiliki anggota terbanyak dan bekerjasama dengan sembilan GAPOKTAN (Lampiran 2).

Menurut (Kotler, 2012), pemasaran adalah proses mengidentifikasi dan memenuhi manusia dengan kebutuhan sosialnya. Salah satu definisi tersingkat dari pemasaranadalah "memenuhi kebutuhan dengan mendapat laba". Definisi pemasaran oleh The American Marketing Association adalah aktivitas, seperangkat institusi, dan proses menciptakan, mengkomunikasikan, mengirimkan, dan bertukar penawaran yang mempunyai nilai bagi customer, klien, partner, maupun masyarakat pada umumnya.

Teknologi :Alat atau mesin yang digunakan dalam proses panen pada koperasi Tani Sawit Barokah di Desa Teluk Kasai Rambahan adalah mesin atau alat teknologi modern yaitu egrek. Egrek adalah alat untuk memanen kelapa sawit pada pohon yang sudah tinggi, lebih dari 3 meter. Jumlah mesin atau alat yang digunakan dalam proses panen sawit koperasi Tani Sawit Barokah di Desa Teluk Kasai Rambahan adalah sebanyak 1 unit yaitu egrek. Kualitas alat atau mesin yang digunakan sangat baik. Teknisi alat atau mesin yang digunakan dalam proses panen sawit tidak tersedia. Selanjutnya tempat yang digunakan untuk hasil panen adalah langsung dijual agar tidak mengurangi kualitas kelapa sawit. Kualitas tempat yang digunakan yaitu baik. Penggunaan Merk pada tempat yaitu jelas.
Lama waktu yang dibutuhkan dari proses panen sampai sawit siap dijual yaitu selama 4 hari karena selain kelapa sawit yang tinggi dan juga alat yang digunakan masih kurang. Mobilitas pada koperasi Tani Sawit Barokah di Desa Teluk Kasai Rambahan lancar. Letak lokasi pada koperasi Tani Sawit Barokah di Desa Teluk Kasai Rambahan ini strategis karena berada di pinggir jalan utama Tebo Ulu.

Menurut Gie (1996), Teknologi ternyata sangat beragam. Teknologi merupakan hal yang sangat rumit, teknologi yaitu barang buatan sebagai kegiatan manusia, sebagai kumpulan pengetahuan dan sebagai suatu sistem. Teknologi harus dianggap sebagai suatu sistem, yaitu suatu kumpulan dari satuansatuan dan kegiatan-kegiatan yang saling berkaitan dan saling berkomunikasi sebagai suatu sistem maka teknologi akan memiliki tujuan, komponen-komponen, adanya pengaruh lingkungan, dan diperlukan aspek manajemen sistem. Objek yang mencakup fasilitas fisik seperti mesin, dan peralatan yang dapat meningkatkan kekuatan fisik manusia.

\section{Analisis Faktor Internal dan Eksternal Koperasi Tani Sawit Barokah di Desa Teluk Kasai Rambahan Kecamatan Tebo Ulu Kabupaten Tebo.}

Analisis Faktor Internal :Faktor internal terdiri dari kekuatan dan kelemahan yang ada pada koperasi Tani Sawit Barokah di Desa Teluk Kasai Rambahan Kecamatan Tebo Ulu Kabupaten Tebo. Faktor kekuatan dan kelemahan didapat dari kuesioner yang dilakukan secara wawancara langsung kepada ketua koperasi tani sawit barokah, kemudian rating dan bobot diperoleh dari kuesioner tersebut. Menurut Rangkuti (2006), pemberian bobot pada analisis faktor internal dan eksternal tidak boleh melebihi 1,00. Hal ini dapat dilihat pada Tabel 1 . 
Tabel 1. Faktor-faktor Strategi Internal

\begin{tabular}{|c|c|c|c|}
\hline Faktor-faktor Internal & Bobot & Rating & Bobot X Rating \\
\hline \multicolumn{4}{|l|}{ Kekuatan } \\
\hline 1. Sumber modal sendiri & 0,20 & 4 & 0,80 \\
\hline $\begin{array}{l}\text { 2. Anggota sangat mudah } \\
\text { ditemukan }\end{array}$ & 0,20 & 4 & 0,80 \\
\hline $\begin{array}{l}\text { 3. Modal simpanan pokok } \\
\text { awal terjangkau }\end{array}$ & 0,05 & 1 & 0,05 \\
\hline \multicolumn{4}{|l|}{ Kelemahan } \\
\hline $\begin{array}{l}\text { 1. Tidak adanya investasi dari } \\
\text { pihak lain }\end{array}$ & 0,20 & 1 & 0,20 \\
\hline $\begin{array}{l}\text { 2. Menghasilkan sawit tidak } \\
\text { menentu }\end{array}$ & 0,20 & 1 & 0,20 \\
\hline \multirow[t]{2}{*}{$\begin{array}{l}\text { 3. Pembukuan dilakukan setiap } \\
\text { tahun }\end{array}$} & 0,15 & 2 & 0,30 \\
\hline & $\mathbf{1 , 0 0}$ & & 2,35 \\
\hline
\end{tabular}

Sumber : Analisis Data Primer (2020)

Tabel 1 diatas menunjukkan bahwa kekuatan yang dimiliki oleh koperasi tani sawit barokah di Desa Teluk Kasai Rambahan Kecamatan Tebo Ulu Kabupaten Tebo ini adalah sumber modal merupakan modal simpanan pokok Bapak Abdul Roni S.Pd itu sendiri dengan skor 0,80 dan anggota sangat mudah ditemukan dengan skor 0,80 selanjutnya yaitu modal simpanan pokok awal terjangkau dengan skor 0,05 dengan begitu dapat mempermudah dalam pengembangan koperasi tani sawit barokah.

Koperasi tani sawit barokah di Desa Teluk Kasai Rambahan Kecamatan Tebo Ulu Kabupaten Tebo ini juga memiliki kelemahan yaitu tidak adanya investasi dari pihak lain dengan skor 0,20 dan menghasilkan sawit tidak menentu atau tergantung matangnya sawit dengan skor 0,20 yang berakibat koperasi ini belum berjalan dengan baik selanjutnya yaitu pembukuan dilakukan setiap tahun dengan skor 0,30. Penggabungan faktor kekuatan dan kelemahan pada koperasi tani sawit barokaah memperoleh total skor 2,35 .

Analisis Faktor Eksternal :Faktor eksternal terdiri dari peluang dan ancaman yang ada pada koperasi Tani Sawit Barokah di Desa Teluk Kasai Rambahan Kecamatan Tebo UluKabupaten Tebo. Faktor peluang dan ancaman didapat dari kuesioner yang dilakukan secara wawancara langsung kepada ketua koperasi tani sawit barokah, kemudian rating dan bobot diperoleh dari kuesioner tersebut, hal ini dapat dilihat pada Tabel 2. 
Tabel 2. Faktor -faktor Strategi Eksternal

\begin{tabular}{|c|c|c|c|}
\hline Faktor-faktor Eksternal & Bobot & Rating & $\begin{array}{c}\text { Bobot X } \\
\text { Rating }\end{array}$ \\
\hline \multicolumn{4}{|l|}{ Peluang } \\
\hline $\begin{array}{l}\text { 1. Kualitas kelapa sawit yang sangat } \\
\text { baik }\end{array}$ & 0,20 & 4 & 0,80 \\
\hline $\begin{array}{l}\text { 2. Tidak ada pesaing dalam penjualan } \\
\text { sawit koperasi }\end{array}$ & 0,05 & 1 & 0,05 \\
\hline $\begin{array}{l}\text { 3. Keikutsertaan dalam pameran penarik } \\
\text { agar menjual sawit ke koperasi }\end{array}$ & 0,20 & 4 & 0,80 \\
\hline \multicolumn{4}{|l|}{ Ancaman } \\
\hline 1. Pesaing dari koperasi yang sejenis & 0,05 & 4 & 0,20 \\
\hline 2. Kurangnya kegiatan penjualan & 0,15 & 2 & 0,30 \\
\hline $\begin{array}{l}\text { 3. Kurangnya mesin/alat yang } \\
\text { digunakan }\end{array}$ & 0,20 & 1 & 0,20 \\
\hline \multirow[t]{2}{*}{$\begin{array}{l}\text { 4. Image Koperasi tani sawit barokah } \\
\text { yang masih asing di PT. RAU }\end{array}$} & 0,15 & 2 & 0,30 \\
\hline & $\mathbf{1 , 0 0}$ & & 2,65 \\
\hline
\end{tabular}

Sumber : Analisis Data Primer (2020)

Tabel 2 diatas menunjukkan bahwa peluang yang memiliki oleh koperasi tani sawit barokah di Desa Teluk Kasai Rambahan Kecamatan Tebo Ulu Kabupaten Tebo adalah kualitas kelapa sawit yang sangat baik memiliki skor 0,80 dikarenakan koperasi ini selain kesuburan pohon dan koperasi juga memperhatikan proses pemanenan agar tidak salah memetik sebelum waktunya panen jika salah maka dapat mengurangi kualitas sawit .Kemudian tidak adanya pesaing dalam koperasi tani sawit barokah memiliki skor 0,05 selanjutnya keikutsertaan dalam pameran karena sangat berpengaruh dalam meningkatkan penjualan dan untuk memperkenalkan lebih luas tentang pengaruh harga penjualan sawit yang melalui koperasi memiliki skor 0,80 .

koperasi tani sawit barokah di Desa Teluk Kasai Rambahan Kecamatan Tebo Ulu Kabupaten Tebo ini juga terdapat berbagai ancaman yaitu pesaing dari koperasi lain yang sejenis yang menjadi ancaman bagi koperasi ini memiliki skor 0,20 kemudian kurangnya kegiatan penjualan menyebabkan masyarakat kurang mengetahui tentang koperasi ini memiliki skor 0,30. Kurangnya mesin/alat yang digunakan memiliki skor 0,20 selanjutnya yang terakhir adalah image koperasi tani sawit barokah yang masih asing di PT. RAU memiliki skor 0,30 dikarenakan masyarakat beranggapan bahwa koperasi ini tidak mempengaruhi harga penjualan kelapa sawit. Gabungan antara faktor peluang dan ancaman yang ada pada koperasi tani sawit barokah ini memiliki skor 2,65.

\section{Matriks IE (Internal dan Eksternal)}

Dari total skor yang diperoleh, yaitu faktor strategi internal 2,35, sedangkan total skor yang diperoleh dari anaalisis faktor eksternal adalah sebesar 2,65. Dengan demikian posisi Koperasi Tani Sawit Barokah di Desa Teluk Kasai Rambahan dapat dilihat paga gambar 4. 
Total Faktor Strategi Internal

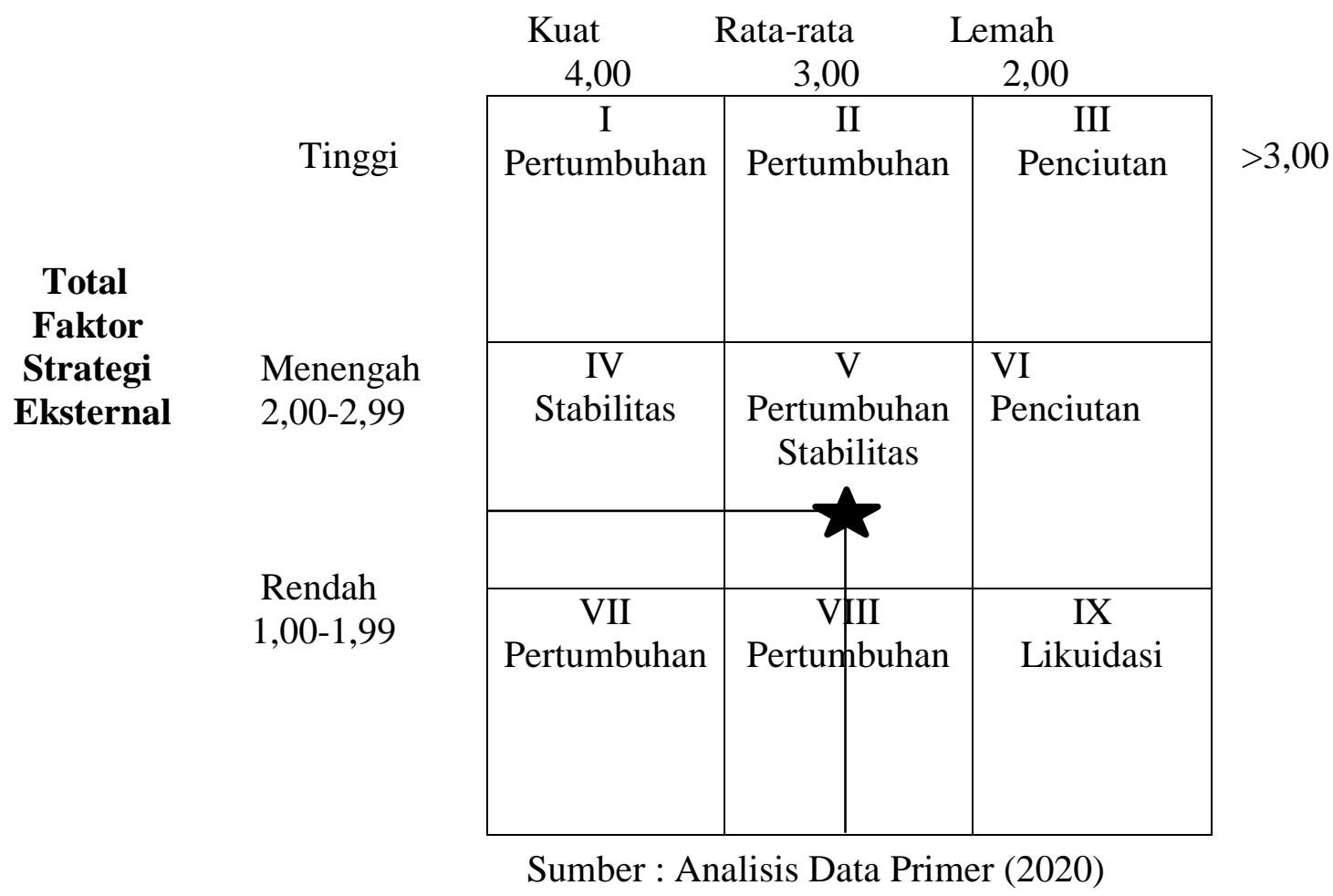

Gambar 2. Matriks Internal dan Eksternal Koperasi Tani Sawit Barokah di Desa Teluk Kasai Rambahan

Gambar 4 diatas menunjukkan skor yang diperoleh dari faktor strategis internal 2,35 dan faktor strategis eksternal 2,65 menunjukkan titik koordinat terletak pada daerah V. Sehingga strategi yang tepat untuk digunakan dalam pengembangan koperasi Tani Sawit Barokah di Desa Teluk Kasai Rambahan Kecamatan Tebo Ulu Kabupaten Tebo adalah strategi pertahanan dan pelihara. Strategi yang digunakan adalah strategi konsentrasi melalui horizontal atau stabilitas seperti mempertahankan kualitas sawit koperasi, memperluas penjualan sehingga lebih terkenal, peningkatan teknologi tepat guna dan pengembangan kerja sama antar Gabungan Kelompok Tani (GAPOKTAN) di Desa Teluk Kasai Rambahan Kecamatan Tebo Ulu Kabupaten Tebo.

\section{Matriks SWOT Strategi Pengembangan Koperasi Tani}

\section{Sawit Barokah di Desa Teluk Kasai Rambahan Kecamatan Tebo Ulu Kabupaten Tebo.}

Matriks SWOT digunakan untuk menyusun srtategi perusahaan matriks ini dapat menggambarkan secara jelas bagaimana peluang dan ancaman eksternal yang dihadapi perusahaan dapat disesuaikan dengan kekuatan dan kelemahan yang dimilikinya.

Matriks SWOT digunakan dalam identifikasi berbagai faktor secara sistematis untuk merumuskan strategi perusahaan. Analisis ini menggunakan logika dalam memaksimalkan pemakaian kekuatan dan peluang untuk memanipulasi kelemahan dan ancaman dan meminimalkan ancaman. Matriks SWOT strategi pengembangan Koperasi Tani Sawit Barokah di Desa Teluk Kasai 
Rambahan Kecamatan Tebo Ulu 2.

Kabupaten Tebo dapat dilihat pada Tabel

Tabel 3. Matriks SWOT Strategi Pengembangan Koperasi Tani Sawit Barokah di Desa Teluk Kasai Rambahan Kecamatan Tebo Ulu Kabupaten Tebo

\begin{tabular}{|c|c|c|}
\hline EFAS & $\begin{array}{ll} & \text { STRENGHT (S) } \\
\text { 1. } & \text { Sumber modal sendiri } \\
\text { 2. Anggota sangat mudah } \\
\text { ditemukan } \\
\text { 3. } \\
\text { Modal simpanan pokok } \\
\text { awal terjangkau }\end{array}$ & 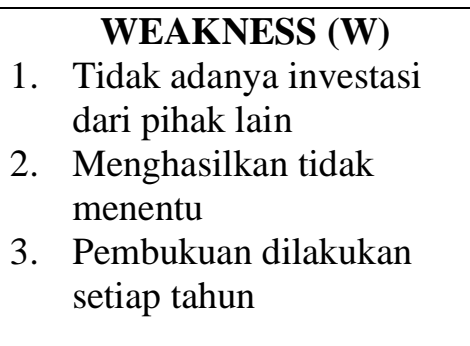 \\
\hline $\begin{array}{l}\text { OPPORTUNITY }(\mathbf{O}) \\
\text { 1. Kualitas kelapa } \\
\text { sawit yang sangat } \\
\text { baik } \\
\text { 2. } \begin{array}{l}\text { Tidak ada pesaing } \\
\text { dalam penjualan }\end{array} \\
\text { sawit koperasi } \\
\text { 3. Keikutsertaan dalam } \\
\text { pameran untuk } \\
\text { penarik agar } \\
\text { menjual sawit ke } \\
\text { koperasi }\end{array}$ & $\begin{array}{l}\text { STRATEGIS S-O } \\
\text { 1. Peningkatan modal } \\
\text { dengan cara } \\
\text { penambahan investasi } \\
\text { atau pinjaman dari } \\
\text { pihak lain } \\
\text { (S1,S2,S3,O1,O2,0 } \\
\text { 2. } \begin{array}{l}\text { Memperluas daerah } \\
\text { penjualan } \\
(\mathrm{S} 1, \mathrm{~S} 3, \mathrm{O} 2, \mathrm{O} 3)\end{array}\end{array}$ & 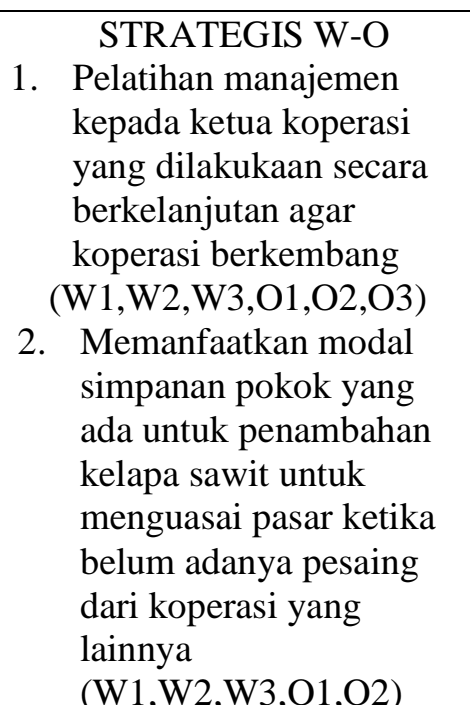 \\
\hline $\begin{array}{l}\text { TREATH (T) } \\
\text { 1. Pesaing dari } \\
\text { koperasi yang } \\
\text { sejenis } \\
\text { 2. Kurangnya kegiatan } \\
\text { penjualan } \\
\text { 3. Kurangnya mesin/alat } \\
\text { yang digunakan } \\
\text { 4. Image Koperasi tani } \\
\text { masyarakat yang } \\
\text { masih asing di PT. } \\
\text { RAU }\end{array}$ & $\begin{array}{ll}\text { STRATEGIS S-T } \\
\text { 1. } \\
\text { Menciptakan penjualan } \\
\text { yang baru koperasi } \\
(\mathrm{S} 1, \mathrm{~T} 1, \mathrm{~T} 2, \mathrm{~T} 3) \\
\text { 2. } \\
\text { Memperluas pangsa } \\
\text { pasar } \\
\text { (S1,S2,T1,T2,T3,T4) } \\
\text { 3. Mempertahankan } \\
\text { kualitas sawit agar tetap } \\
\text { mampu bersaing dengan } \\
\text { sawit lain } \\
\text { (S1,T1,T4) }\end{array}$ & 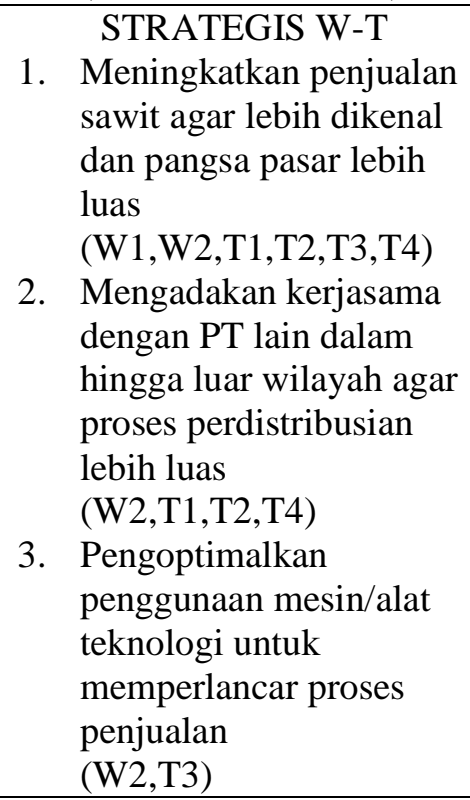 \\
\hline
\end{tabular}

Sumber : Analisis Data Primer (2020)

Tabel 3 diatas menunjukkan bahwa hasil dari identifikasi faktor internal berupa kekuatan dan kelemahan dan faktor eksternal berupa peluang dan ancaman dalam mengembangkan koperasi Tani Sawit Barokah Teluk Kasai Rambahan Kecamatan Tebo Ulu Kabupaten Tebo 
antara lain didapatkan strategi sebagai berikut :

1. Strategi S-O (Strenght-Opportunity) Strategi S-O (StrenghtOpportunity) atau kekuatan-peluang adalah strategi yang digunakan untuk memaksimalkan kekuatan dan memanfaatkan peluang yang ada, yaitu :

a. Peningkatan modal dengan cara penambahan investasi atau pinjaman dari pihak lain(SO-1).

b. Memperluas daerah penjualan (SO-2).

2. Strategi W-O (Weakness- Opportunity) Straategi W-O (WeaknessOpportunity) atau kelemahan-peluang adalah strategi yang digunakan meminimalkan kelemahan dan memanfaatkan peluang yang ada, yaitu :

a. Pelatihan manajemen kepada ketua koperasi yang dilakukan secara berkelanjutan agar koperasi berkembang(WO-1).

b. Memanfaatkan modal simpanan pokok yang ada untuk penambahan kelapa sawit untuk menguasai pasar ketika belum adanya pesaing dari koperasi lainnya (WO-2).

3. Strategi S-T (Strenght-Treaths)

Strategi S-T (Strenght-Treaths) atau strategi kekuatan-ancaman adalah strategi yang digunakan untuk memaksimalkan kekuatan dan mengatasi ancaman. Alternatif strategi yang dilakukan adalah sebagai berikut :

a. Menciptakan penjualan yang baru koperasi (ST-1).

b. Memperluas pangsa pasar (ST-2).

c. Mempertahankan kualitas sawit agar tetap mampu bersaing dengan sawit lain (ST-3).

4. Strategi W-T (Weakness-Treaths) Strategi W-T (WeaknessTreaths)atau kelemahan-ancaman merupakan strategi yang diguunakan untuk meminimalkan kelemahan dan mengatasi ancaman. Alternatif strategi yang digunakan adalah sebaagai berikut :

a. Meningkatkan penjualan sawit agar lebih dikenal dan pamgsa pasar lebih luas (WT-1). b. Mengadakan kerjasama dengan PT lain dalam hingga luar wilayah agar proses pendistribusian lebih luas (WT-2).

c. Pengoptimalkan penggunaan mesin/alat teknologi untuk memperlancarkan proses penjualan (WT-3).

\section{KESIMPULAN DAN SARAN}

\section{Kesimpulan}

1. Faktor internal dan eksternal a. Faktor Internal (kekuatan dan kelemahan)

$$
\text { Koperasi Tani Sawit }
$$

Barokah di Desa Teluk Kasai Rambahan Kecamatan Tebo Ulu Kabupaten Tebo memiliki faktor internal berupa kekuatan dan kelemahan sebagai berikut :

- Kekuatan

$>$ Sumber modal sendiri

$>$ Anggota sangat mudah ditemukan

$>$ Modal simpanan pokok awal terjangkau

- Kelemahan

$>$ Tidak adanya investasi dari pihak lain

$>$ Menghasilkan sawit tidak menentu

$>$ Pembukuan dilakukan setiap tahun

b. Faktor Eksternal (peluang dan ancaman)

Koperasi Tani Sawit Barokah di Desa Teluk Kasai Rambahan Kecamatan Tebo Ulu Kabupaten Tebo memiliki faktor eksternal berupa peluang dan ancaman sebagai berikut :

- Peluang

$>$ Kualitas kelapa sawit yang sangat baik

Tidak ada pesaing dalam pejualan sawit koperasi

$>$ Keikutsertaan dalam pameran untuk penarik 
- Ancaman

agar menjual sawit ke koperasi

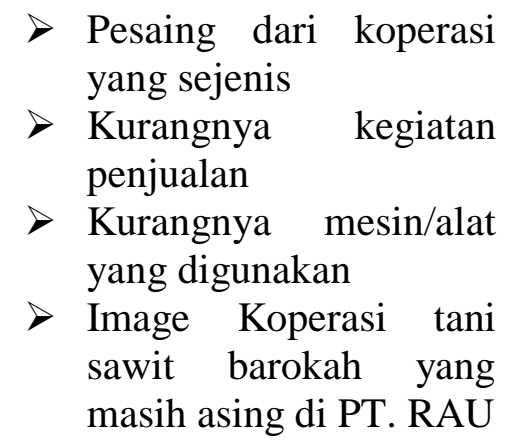

2. Strategi pengembangan yang tepat digunakan untuk Koperasi Tani Sawit Barokah di Desa Teluk Kasai Rambahan Kecamatan Tebo Ulu Kabupaten Tebo adalah sebagai berikut :

a. Peningkatkan modal dengan cara penambahan investasi atau pinjaman dari pihak lain.

b. Memperluas daerah penjualan.

c. Pelatihan manajemen kepada ketua koperasi yang dilakukaan secara berkelanjutan agar koperasi berkembang.

d. Memanfaatkan modal simpanan pokok yang ada untuk penambahan kelapa sawit untuk menguasai pasar ketika belum adanya pesaing dari koperasi yang lainnya.

\section{DAFTAR PUSTAKA}

Badan pusat statistik Kabupaten Tebo.2019. Jumlah Desa/Kelurahan di Kabupaten Tebo.

Dinas koperasi dan usaha kecil menengah Provinsi jambi.2019. Jumlah koperasiyang aktif dan tidak aktif di Kabupaten Tebo.

Fikriman, F. (2017). Tranformasi Pertanian dan Pembangunan Pedesaan. JAS (Jurnal Agri Sains), 1(2).

Fikriman, F., \& Herdiansyah, A. (2017). Faktor-faktor yang Mempengaruhi e. Menciptakan penjualan yang baru koperasi.

f. Memperluas pangsa pasar.

g. Mempertahankan kualitas sawit agar tetap mampu bersaing dengan sawit lain.

h. Meningkatkan penjualan sawit agar lebih dikenal dan pangsa pasar lebih luas.

i. Mengadakan kerjasama dengan PT lain dalam hingga luar wilayah agar proses perdistribusian lebih luas.

j. Pengoptimalkan penggunaan mesin/alat teknologi untuk memperlancar proses penjualan.

\section{Saran}

Koperasi Tani Sawit Barokah di Desa Teluk Kasai Rambahan Kecamatan Tebo Ulu Kabupaten Tebo lebih meningkatkan kegiatan penjualan sawit agar sawit koperasi dikenal PT. RAU secara umum dan menjangkau pasar yang lebih luas sehingga dapat bersaing dengan koperasi sejenis dari daerah lain. Mempertahankan ciri dan kualitas sawit koperasi yaitu dengan menciptakan penjualan yang baru, penambahan Gabungan Kelompok Tani agar memiliki daya tarik yang tinggi agar tetap mampu bersaing dengan koperasi lain.

Produktivitas Tenaga Kerja Buruh Panen Buah Kelapa Sawit (studi Kasus pada Divisi I PT. Megasawindo Perkasa Ikecamatan Pelepat Kabupaten Bungo). JAS (Jurnal Agri Sains), 1(1).

Gie,T.L. 1996. Pengantar Filsafat Teknologi. Penerbit Andi. Yogyakarta

Hasibuan Malayu S.P, 2006. Manajemen Sumber Daya Manusia. Edisi Revisi, Cetakan Kedelapan PT. Bumi Aksara, Jakarta. 
Kotler,Et.Al Philip and Keller, K.L. (2012). Marketing Management (14thed). New Jersey: Prentice Hall.

Rangkuti, F. 2005. Analisis SWOT Teknik Membelah Kasus Bisnis.PT. Gramedia Pustaka Utama. Jakarta. Sugiono.2009.Metode Penelitian Bisnis. Alfabeta . Bandung.
Syahrudin, H. 2003. Hubungan antara Manfaat Koperasi dengan Partisipasi Anggota. Tesis. UNPAD. Bandung.

UU No 251992, Pasal 5 Bagian Kedua tentang prinsip Koperasi.

Weston, J. Fred dan E.F., Brigham., 2001, Manajemen Keuangan. Jakarta : Erlangga. 